\title{
ЛIТЕРАТУРА
}

History, 2017 - History / Maria Curie Skłodowska University. Retrieved from: https://www.umcs.pl/en/history,3127.htm\#page-2.

Internationalization Strategy, 2017 - Internationalization Strategy / Maria Curie Skłodowska University. Retrieved from: https://www.umcs.pl/en/internationalization,9660.htm.

Leadership, 2017 - Leadership of the Political Science Faculty / Maria Curie Skłodowska University. Retrieved from: https://www.umcs.pl/en/leadership,10201.htm.

MCSU, 2017 - Maria Curie Skłodowska University Official Site / Maria Curie Skłodowska University. Retrieved from: https://www.umcs.pl/en/.

Perspektywy, 2017 - Perspektywy University Ranking 2017. Internationalization / Perspektywy. Retrieved from: http://ranking.perspektywy.org/2017/ranking-uczelni-akademickich/ranking-uczelni-akademickich-wggrup-kryteriow/umiedzynarodowienie.

Statistics, 2017 - Statistics of the Political Science Faculty / Maria Curie Skłodowska University. Retrieved from: https://www.umcs.pl/en/incoming-students, 12774.htm.

УДК 373.3.016: 51-048.35]:005.336.4(4)

Валентина Панченко, старший викладач кафедри педагогіки, теорії та методики початкової освіти

ДВНЗ «Переяслав-Хмельницький державний педагогічний університет імені Григорія Сковороди».

E-mail: pan_val@ukr.net

DOI 10.31470/2308-5126-2019-45-2-79-85

ORCID 0000-0002-3480-4301

\section{МОДЕРНІЗАЦІЯ ЗМІСТУ ПОЧАТКОВОЇ МАТЕМАТИЧНОЇ ОСВІТИ В УКРАЇНІ З УРАХУВАННЯМ ДОСВІДУ КРАЇН ЄВРОПЕЙСЬКОГО СОЮЗУ}

У статті досліджено проблему модернізачії змісту математичної освіти учнів початкових класів на основі досвіду країн Свропейського Союзу. Розглянуто типову модель освітньої системи в країнах ЄС, схарактеризовано модель державного стандарту та навчальних програм із математики, виокремлено компетенціі, характерні для навчальних програм. Розглянуто прочеси оновлення педагогічної та математичної освіти в Україні. Визначено змістові лінії математичної освітньої галузі Держсавного стандарту початкової освіти; теоретично обтрунтовано та розкрито компетентнісну спрямованість оновлених навчальних програм з математики. Здійснено перелік математичних знань, відображених у вигляді термінів, уявлень, понять, законів, залежностей, властивостей, які повинні засвоїти учні початкових класів; наведено приклади розумових та практичних умінь, які формуються в учнів початкової школи; виокремлено рівні навчальних досягнень учнів та вимоги до очінювання усних та письмових відповідей учнів. Проаналізовано підходи до прочесів модернізачії початкової математичної освіти в Україні.

Ключові слова: математична освіта, модернізачія, компетентнісний підхід, компетенції, державний стандарт, навчальні програми, змістові лінії.

The article deals with the problem of modernizing the content of mathematical education of the primary school students on the basis of the experience of the European Union countries. It is determined that a personcenteredch, integration, informatization, competence approach also apply to the primary education. The typical model of the educational system in the EU countries is considered, which includes a list of general objectives and objectives of teaching the particular subjects, a basic curriculum that divides a studytime between the subject fields/subjects, standards of the subject areas that determine the minimum content of curricula and the succession of study the educational material, requirements to the level of the students' progress in the subject areas of the educational subjects. The processes of updating the pedagogical and mathematical education in Ukraine are considered. It is indicated that the main goal of education is a comprehensive development of the student's personality, his talents, abilities, competencies and cross-cutting abilities. It is stated that humanitarization and humanization, person-centered model of education, reforming and modernization are to ensure the proper quality of mathematical education, the fundamentality of mathematical training, the formation of a mathematical style of thinking, the effectiveness of the mathematical knowledge's application. The model of the state standard and educational programs in Mathematics is characterized, the competencies characteristic for the curricula are singled 
out. The purpose of the mathematical educational branch is defined, which consists in the formation of mathematical and other key competencies, the development of thinking, the ability to recognize and simulate the processes and situations in everyday life, which can be solved by using the mathematical methods. The content lines of the mathematical educational branch of the State standard of primary education are determined; the competence orientation of updated educational programs in Mathematics is theoretically grounded and revealed. A list of the mathematical knowledge displayed in the form of terms, impressions, concepts, laws, dependencies, properties, which must be learned by the primary school students, is accomplished; examples of the mental and practical skills that are formed in the primary school students are given; levels of the students' educational achievements and the requirements for the assessment of the students' oral and written responses are identified. The approaches to the modernization of primary mathematical education in Ukraine are analyzed.

Keywords: mathematical education, modernization, competence approach, competencies, state standard, curricula, content lines.

Постановка проблеми. Модернізація змісту освіти в Україні відбувається на основі досвіду країн Європейського Союзу. Усі світові тенденції та інновації стосуються і початкової ланки освіти, зокрема: особистісно-орієнтований підхід, інтеграція, інформатизація, компетентнісний підхід. Адже в українській системі освіти переважав знаннєвий підхід, при якому результатом навчання була сукупність накопичених школярем знань, умінь i навичок. У сучасному інформаційному суспільстві формується нова система цінностей, у якій володіння знаннями, уміннями й навичками є необхідним, але й недостатнім результатом навчання. Головна мета освіти полягає у всебічному розвитку особистості учня, iї талантів, здібностей, компетентностей та наскрізних умінь. Початкова математична освіта теж потребує оновлення змісту навчання. Ці проблеми вказують на необхідність вивчення й використання позитивних результатів зарубіжного досвіду для розбудови початкової школи та інтеграції України в єдиний освітній простір. Ураховуючи вище сказане, переконуємося, що дана проблема є актуальною.

Аналіз останніх досліджень $\boldsymbol{i}$ публікацій. Стан початкової математичної освіти, проблеми та пошук шляхів їх вирішення $є$ предметом вивчення вітчизняних і зарубіжних методистів, науковців, учителів-практиків. Дослідженням проблем початкової математичної освіти та іï порівнянням 3 європейською займаються Л. Коваль, О. Локшина. Питанню оновлення змісту навчання математики в початковій школі присвячені розвідки М. Богдановича, О. Гайштута, Л. Коваль, М. Козак, Я. Короля, О. Корчевської, Л. Кочиної, М. Левшина, Н. Листопад, С. Логачевської, О. Митника, С. Скворцової та ін. Хоча вивченням проблем початкової математичної освіти та пошуком шляхів підвищення ефективної підготовки молодших школярів займається низка науковців, більш детального та грунтовного аналізу потребує іiі стан на сучасному етапі.

Метою cmammi $\epsilon$ теоретичне обгрунтування та розкриття проблеми модернізації змісту математичної освіти в початковій школі.

Виклад основного матеріалу. Стандартизація змісту освіти країн Європейського Союзу $є$ ефективним інструментом забезпечення якості освіти. Стандарти, що використовуються країнами $\mathrm{CC}$, працюють за допомогою двох компонентів - інваріантної та варіативної частини, які забезпечують особистісне засвоєння кожним учнем достатнім мінімум знань та вмінь, а також окреслюють результати, яких учень повинен досягти в процесі навчання. Типова модель освітнього стандарту в країнах Свросоюзу включає: «перелік загальних цілей і цілей навчання окремих предметів; базовий навчальний план, який розподіляє навчальний час за предметними галузями/предметами; стандарти предметних галузей, які визначають обов'язковий мінімум змісту навчальних програм та послідовність 
вивчення навчального матеріалу; вимоги до рівня успішності учнів 3 предметних галузей навчальних предметів» [Локиина, 2009: c. 129]. Характерною ознакою типової моделі стандарту $є$ те, що він не $є$ незмінним, а постійно змінюється відповідно до суспільних вимог до освіти. Для навчальних програм із математики країн ЄС характерні такі види компетенцій: засвоєння базових навичок і алгоритмів діяльності, розуміння математичних понять і принципів, застосування математики в ситуаціях реального життя, спілкування на математичні теми та вміння мислити математично. Порівнюючи цілі та завдання вивчення початкового курсу математики, можна побачити їхню злагодженість 3 вимогами, що існують в країнах Свропейського Союзу.

Вивчаючи досвід учителів початкової школи в навчанні математики та наукові дослідження, які проводяться в Україні та в країнах Свропейського Союзу, переконуємося, що математичні знання необхідні в науково-практичній діяльності людства.

Під впливом викликів сучасності, як стверджує О. Локшина, математична складова перетворилася на математично-технологічну, адже, крім традиційної математики, яка вивчається в усіх країнах Європейського Союзу з 1-го класу, вона збагачується на такі предмети або теми, як інформаційно-комунікаційні технології. В усіх країнах ЄС математика - окремий предмет у розкладі початкової школи, на яку відводиться 3-4 години на тиждень; акцент при навчанні робиться на трансляції таких понять, як число, форма, величини та на формування прикладних навичок застосування теоретичних знань [Локшина,2009: c. 174]. ІКТ-грамотність у європейських країнах $\epsilon$ необхідним інструментом для подальшого успішного навчання кожного учня. За умови включення цього предмета до стандарту початкової освіти знання та вміння можуть транслювати учням як у форматі окремого навчального предмета, так і під час навчання інших. У більшості країн Європейського Союзу інформаційно-комунікаційні технології використовують як засіб навчання перш за все базових умінь читання, письма та лічби.

Як бачимо, процеси розбудови початкової математичної освіти мають свої особливості, але вони невіддільні від процесів оновлення педагогічної та математичної освіти в Україні. Сучасна педагогічна наука висвітлює напрями перебудови відповідно до державних стандартів та через практичне впровадження нових технологій навчання. Гуманітаризація та гуманізація, особистісно орієнтована модель навчання, реформування та модернізація повинні забезпечити належну якість математичної освіти, фундаментальність математичної підготовки, формування математичного стилю мислення, дієвість застосування математичних знань.

Модернізація змісту освіти - це перебудова певної сторони навчального процесу, які не змінюють основ існуючої структури математичної освіти. Процеси модернізації початкової школи полягають в осучасненні знань традиційних складових та запровадженні нових.

Т. Фадєєва визначає різні підходи у сучасних процесах модернізації початкової математичної освіти: теоретико-методологічний, який характеризує теоретичні основи розвитку математичного мислення; інтуїтивно-практичний, який зорієнтований на засвоєння учнями математичних понять, законів і переслідує практичну мету: виконувати арифметичні дії, розв'язувати задачі, рівняння, будувати геометричні фігури тощо. Когнітивний підхід сприяє розвитку процесів мислення та інтелектуальних операцій; інформаційно-логічний підхід формує функції навчання з позицій інформатики. 
Над розробкою та удосконаленням програм і методичного забезпечення початкового курсу математики працювали М. Бантова, Г. Бельтюкова, М. Богданович, П. Ерднієв, Н. Істоміна, Я. Король, Л. Кочина, Л. Коваль, Н. Листопад, Л. Петерсон, С. Скворцова, О. Онопрієнко та ін.

Науковці вважають, що для модернізації змісту початкової математичної освіти потрібно реалізувати такі ідеї, як використання Державного стандарту як основного механізму нормативної регуляції змісту, реалізації його вимог щодо математичного розвитку молодших школярів; організацію навчання математики в початковій школі на принципах гуманізації, цілісності, наступності, загальнолюдських і національних цінностей, потреб загальнокультурного розвитку молодших школярів; збагачення змісту математичної підготовки молодших школярів мотиваційним, виховним i розвиваючим матеріалом; активного впровадження компетентнісного, особистісно-діяльнісного підходів під час навчання молодших школярів; варіативності реалізації змісту початкової математичної освіти шляхом упровадження інноваційних технологій, що забезпечує технологізацію змісту та процесу навчання молодших школярів; побудови підручників математики для молодших школярів таким чином, щоб вони включали завдання, які спрямовані на формування ключових і предметних (математичних) компетентностей кожного випускника початкової школи та ін. [Коваль, 2011: c. 15].

Навчання математики в початкових класах має будуватися відповідно до вимог Державного стандарту початкової освіти, який розроблено відповідно до мети початкової школи 3 урахуванням пізнавальних можливостей i потреб учнів початкових класів. Державний стандарт грунтується на засадах особистіснозорієнтованого та компетентнісного підходів, що зумовлює чітке визначення вимог до обов'язкових результатів навчання та компетентностей здобувачів освіти, загальний обсяг їх навчального навантаження у базовому навчальному плані початкової школи [Державний стандарт..., 2018: c. 92]. На основі Державного стандарту складено дві типові освітні програми початкової освіти (під керівництвом Р. Шияна та О. Савченко) відповідно до освітніх галузей, визначених Державним стандартом початкової освіти. У програмах конкретизовано зміст навчального матеріалу за двома циклами (1-2 і 3-4 класи) і подано відповідні вимоги до обов'язкових та очікуваних результатів навчання [Типова освітня програма..., 2018: c. 122, 190]. Обидві програми містять однакові змістові лінії. Відрізняються програми рівнем інтеграції освітніх галузей до навчальних предметів та визначенням очікуваних результатів навчання: у типовій програмі Р. Шияна є розбивка на 1-й та 2-й класи, а в програмі О. Савченко очікувані результати навчання подаються у кінці циклу, тобто після 2-го класу. Зміст навчання у програмі О. Савченко зазначено поряд із очікуваними результатами навчання, а у програмі Р. Шияна орієнтовний зміст подано після результатів кожної змістової лінії. На основі типової освітньої програми або на основі Державного стандарту заклад початкової освіти складає власну освітню програму, яка схвалюється педагогічною радою закладу освіти та затверджується його керівником. Для організації освітнього процесу на основі освітньої програми заклад освіти складає та затверджує навчальний план.

Зазначимо, що кожна освітня галузь має освітній потенціал, необхідний для формування ключових компетентностей. Зокрема, математична освітня галузь дає змогу сформувати такі компетентності: «спілкування державною мовою - уміння, що виробляється у процесі навчання математики, а саме лаконічно та зрозуміло формулювати думку, аргументувати, доводити правильність тверджень; спілкування 
іноземними мовами - зіставляти математичний термін або буквене позначення 3 його походженням з іноземної мови; основні компетентності у природничих науках $\mathrm{i}$ технологіях - моделювати процеси, що відбуваються в навколишньому світі; інформаційно-цифрову компетентність - діяти за алгоритмом і складати алгоритми; уміння вчитися - доводити правильність певного судження та власної думки; ініціативність і підприємливість - здійснювати раціональний вибір; соціальну та громадянську компетентності - робити висновки 3 отриманих результатів розв'язування завдань соціального змісту; обізнаність та самовираження у сфері культури - естетично зображувати фігури, графіки, рисунки; екологічну грамотність і здорове життя - ощадливо користуватися природними ресурсами» [Бібік, 2018: c. 16-17].

Математична освітня галузь реалізується в курсі початкової школи через навчальний предмет - математику. Метою математичної освітньої галузі $\epsilon$ формування математичної та інших ключових компетентностей, розвиток мислення, здатності розпізнавати і моделювати процеси та ситуації з повсякденного життя, які можна розв'язувати із застосуванням математичних методів [Державний стандарт..., 2018: c. 95]. Відповідно до базового навчального плану початкової освіти, що міститься у Державному стандарті, математична освітня галузь належить до інваріантної складової з 140 годинами на рік у кожному класі початкової школи. «Молодші школярі дістають початкові уявлення про ті принципи і закони, які лежать в основі математичних чинників, що вивчаються. Це, насамперед, стосується десяткової системи числення та властивостей арифметичних дій. Істотним на початковому етапі $\epsilon$ оволодіння обчислювальними вміннями i навичками» [Богданович, 1999: с. 18].

Складники математичної компетентності - обчислювальні уміння і навички; уміння й навички розв'язування задач; застосування властивостей, правил, алгоритмів, залежностей; виконання вимірювань та геометричних побудов - $\epsilon$ об'єктами поточної і підсумкової перевірок навчальних досягнень учнів початкової школи 3 математики. Навчальні досягнення учнів у 1-2 класах підлягають формальному (вербальному) оцінюванню, у 3-4 - формальному та підсумковому (бальному) оцінюванню. Виділяють 4 рівні навчальних досягнень учнів: початковий (I рівень), середній (II рівень), достатній (III рівень) і високий (IV рівень), якісна характеристика яких для усних відповідей та письмових робіт подана у орієнтовних вимогах до оцінювання навчальних досягнень учнів у системі загальної середньої освіти з предметів інваріантної складової навчального плану.

Зауважимо, що учні початкової школи повинні засвоїти початкові математичні знання, відображені у вигляді: термінів (одноцифрові числа, доданок, сума, чисельник, знаменник тощо); уявлень (натуральний ряд чисел, числовий вираз і його значення, рівняння з однією змінною, довжина, відстань, периметр тощо); понять (десяток, задача, розряди і класи чисел, дріб, площа фігури); законів (переставний i сполучний закони додавання i множення, розподільний закон множення); залежностей (між компонентами і результатами дій, між швидкістю, часом і відстанню тощо); властивостей (частки, прямокутника) тощо [Oнопрієнко, 2014: c. 10].

Учні в початковій школі навчаються визначати кількість одиниць кожного розряду; усно обчислювати в межах ста; застосовувати вивчені закони і властивості арифметичних дій під час обчислень; здійснювати перевірку щодо правильності виконаних арифметичних дій; знаходити значення числових виразів; розв'язувати 
рівняння з однією змінною та ін. Серед практичних умінь виділяємо уміння записати й прочитати числа в межах мільйона; письмове виконання арифметичних дій у межах мільйона, ділення 3 остачею; побудова прямокутного трикутника, прямокутника (квадрата) з указаними довжинами сторін; вимірювання часових проміжків за допомогою годинника та ін.

Прості уміння молодших школярів за умови належної практики перетворюються в навички діяльності, що полягають у здатності виконувати будьякі дії автоматично. У початковому курсі математики учні формують навички порядкової лічби чисел, додавання у межах 10, базоване на знанні складу числа, виконання табличного множення, скороченого запису одиниць вимірювання величин та ін. Кожен із цих компонентів, що входять до структури компетенції, відображений у їі змісті та назві.

Висновки. Отже, незважаючи на зусилля науковців і педагогів щодо підвищення якості навчання математичної освітньої галузі, потрібно більш результативно впроваджувати такі виклики: врахування індивідуальних особливостей i потреб учнів; ранній, ще 3 довкілля, початок математичної підготовки учнів; адаптація змісту підручників з математики для початкової школи до розвантажених і модернізованих навчальних програм; професійний розвиток учителів початкових класів; впровадження навчальних стратегій та інформаційнокомунікаційних технологій на уроках математики; залучення батьків до формування числової грамотності молодших школярів. Перспективним вбачається вивчення шляхів подолання зазначених труднощів 3 метою використання позитивного досвіду країн Свропейського Союзу в українській системі освіти.

\section{ЛІТЕРАТУРА}

Бібік, 2018 - Нова українська школа: порадник для вчителя / за заг.ред. Н. М. Бібік. - Київ: Літера ЛТД, 2018. $-160 \mathrm{c}$.

Білоножко, 2015 - Білоножко О. А. Формування усного та писемного мовлення на уроках математики / О. А. Білоножко // Математика в школах України. - 2015. - № 6. - С. 10-11.

Богданович, 1998 - Богданович М. В. та ін. Методика викладання математики в початкових класах: Навчальний посібник для студентів педагогічних навчальних закладів. // М. В. Богданович, М. В. Козак, Я. А. Коваль. - К.: «А.С.К.», 1998. - 342 с.

Державний стандарт..., 2018 - Державний стандарт початкової освіти // Типові освітні програми для закладів загальної середньої освіти : 1-2 класи. - К. : ТД «ОСВІТА-ЦЕНТР+», 2018.- С. 92-121.

Коваль, 2011 - Коваль Л. В. Методика навчання математики в початковій школі: теорія і практика / Л. В. Коваль, С. О. Скворцова. - Харків : ЧП «Принт-Лідер», 2011. - 414 с.

Коваль, 2015 - Коваль Л. В. Початкова математична освіта в умовах реформування вітчизняної шкільної галузі / Л. В. Коваль // Наукові записки Бердянського державного педагогічного університету. Сер.: Педагогічні науки. - 2015. - Вип. 1. - С. 86-93.

Локшина, 2009 - Локшина О. І. Зміст шкільної освіти в країнах Європейського Союзу: теорія і практика (друга половина XX - початок XXI ст.): монографія / О. І. Локшина. - К. : Богданова А.М., 2009. $404 \mathrm{c}$.

Онопрієнко, 2014 - Онопрієнко О. Компетентнісний підхід до навчання математики / О. Онопрієнко, Н. Листопад, С. Скворцова. - К. : Редакції газет з дошкільної та початкової освіти, 2014. - 128 с.

Скворияов, 2013 - Скворцова С. О. Підготовка майбутніх учителів початкових класів до навчання молодших школярів розв’язувати сюжетні математичні задачі : [монографія] / С. О. Скворцова, Я. С. Гаєвець. - Х.: Ранок. - НT, 2013. - 332 c.

Типова освітня програма..., 2018 - Типова освітня програма для закладів загальної середньої освіти (розроблена під керівництвом О. Я. Савченко). - К.: ТД «ОСВІТА-ЦЕНТР+», 2018.- С. 190-237.

Типова освітня програма..., 2018 - Типова освітня програма для закладів загальної середньої освіти, 1-2 клас (розроблена під керівництвом Р. Б. Шияна). - К.: ТД «ОСВІТА-ЦЕНТР+», 2018.- С. 122-189. 


\title{
REFERENCES
}

Bibik, 2018 - Nova ukrainska shkola: poradnyk dlia vchytelia / za zah.red. N.M.Bibik. - Kyiv: Litera LTD, 2018. $160 \mathrm{~s}$.

Bilonozhko, 2015 - Bilonozhko O. A. Formuvannia usnoho ta pysemnoho movlennia na urokakh matematyky / O. A. Bilonozhko // Matematyka v shkolakh Ukrainy. - 2015. - №6. - S. 10-11.

Bohdanovych, 1998 - Bohdanovych M. V. ta in. Metodyka vykladannia matematyky v pochatkovykh klasakh : Navchalnyi posibnyk dlia studentiv pedahohichnykh navchalnykh zakladiv. // M. V. Bohdanovych, M. V. Kozak, Ia. A. Koval. - K.: «A.S.K.», 1998. - 342 s.

Derzhavnyi standart..., 2018 - Derzhavnyi standart pochatkovoi osvity // Typovi osvitni prohramy dlia zakladiv zahalnoi serednoi osvity : 1-2 klasy. - K. : TD «OSVITA-TsENTR+», 2018.- S. 92-121.

Koval, 2011 - Koval L. V. Metodyka navchannia matematyky v pochatkovii shkoli : teoriia i praktyka / L. V. Koval, S. O. Skvortsova. - Kharkiv : ChP «Prynt Lider», 2011. - 414 s.

Koval, 2015 - Koval L. V. Pochatkova matematychna osvita v umovakh reformuvannia vitchyznianoi shkilnoi haluzi / L. V. Koval // Naukovi zapysky Berdianskoho derzhavnoho pedahohichnoho universytetu. Ser : Pedahohichni nauky. - 2015. - Vyp. 1. - S. 86-93.

Lokshyna, 2009 - Lokshyna O. I. Zmist shkilnoi osvity v krainakh Yevropeiskoho Soiuzu : teoriia i praktyka (druha polovyna XX - pochatok XXI st.) : monohrafiia / O. I. Lokshyna. - K. : Bohdanova A.M., 2009. - 404 s.

Onopriienko, 2014 - Onopriienko O. Kompetentnisnyi pidkhid do navchannia matematyky / O. Onopriienko, N. Lystopad, S. Skvortsova. - K.: Redaktsii hazet z doshkilnoi ta pochatkovoi osvity, 2014. - $128 \mathrm{~s}$.

Skvortsova, 2013 - Skvortsova S.O. Pidhotovka maibutnikh uchyteliv pochatkovykh klasiv do navchannia molodshykh shkoliariv rozviazuvaty siuzhetni matematychni zadachi : [monohrafiia] / S.O. Skvortsova, Ya.S. Haievets. - Kh. : Ranok -NT, 2013. - 332 s.

Typova osvitnia prohrama..., 2018 - Typova osvitnia prohrama dlia zakladiv zahalnoi serednoi osvity (rozroblena pid kerivnytstvom O. Ya. Savchenko). - K. : TD «OSVITA-TsENTR+», 2018.- S. 190-237.

Typova osvitnia prohrama..., 2018 - Typova osvitnia prohrama dlia zakladiv zahalnoi serednoi osvity, 1-2 klas (rozroblena pid kerivnytstvom R. B. Shyiana). - K. : TD «OSVITA-TsENTR+», 2018.- S. 122-189.

\section{УДК 159.964.21-053.6:316.28-04722}

\section{Тетяна Пономаренко,} аспірант кафедри політичної психологї та сочіально-правових технологій ,

Національного педагогічного університету ім. М.П. Драгоманова.

\section{DOI 10.31470/2308-5126-2019-45-2-85-92}

\author{
E-mail: solovei24081994@gmail.com
}

ORCID 0000-0003-0949-1611

\section{РІВЕНЬ КОМУНІКАТИВНОЇ КОМПЕТЕНТНОСТІ ОСОБИСТОСТІ ЯК ДЕТЕРМІНАНТА КОНФЛІКТОЛОГІЧНОЇ АКТИВНОСТІ ПІДЛІТКІВ}

\begin{abstract}
Стаття присвячена висвітленню проблеми міжособистісного спілкування та розвитку комунікативних умінь підлітків, а також дослідженню впливу комунікабельності особистості на виникнення конфліктів у підлітковому віці. Саме міжособистісне спілкування і є провідною діяльністю иього віку, а конфліктологічна активність підлітків найчастіше пов'язана з постійною переоцінкою иінностей, яка відбувається в процесі спілкування з соиіальним оточенням, формуванням самосвідомості, появою певних установок, стереотипів і власного бачення ситуації. У статті описане дослідження, яке демонструє рівень комунікабельності учнів, рівень їхнього комунікативного контролю, рівень конфліктності, а також стиль поведінки в конфліктній ситуації. Розроблено автором методичні рекомендації для батьків і вчителів щзодо розвитку комунікативної компетентності та психопрофілактики виникнення конфліктів у підлітковому вiųi.
\end{abstract}

Ключові слова: комунікативна компетентність, міжособистісне спілкування, комунікабельність, конфлікт, стиль поведінки у конфлікті, комунікативний контроль, профілактика конфліктів.

This article is about the problem of interpersonal communication and the development of communicative skills of adolescents. The interpersonal communication and the construction of interpersonal interlocutors with a social environment is the leading activity of adolescence. Conflict activity of adolescents is most often associated with revaluation of values that occurs in the process of communicating with the social environment, the formation of self- 